\title{
THE ECOLOGY OF THE TAMAR ESTUARY
}

\section{INTRODUCTION}

\author{
By P. H. T. Hartley, B.Sc. and G. M. Spooner, M.A. \\ From the Plymouth Laboratory
}

(Plate XVIII)

During 1936 and 1937 extensive physical and faunistic studies of the Tamar Estuary were made by several workers at the Plymouth laboratory. These investigations, though conducted independently and with different immediate aims, proved to have considerable bearing on one another, and each worker benefited by occasions for co-operation. As the work proceeded it became clear that one of the most important aspects of each investigation was the bearing it had on the balance of life in the estuary as a whole. It was decided to publish the results of these studies in a series of papers in which each contributor should lay due emphasis on data having possible bearings on the problems studied by the others, so as to present as complete a picture as possible.

Studies have been made of salinity, temperature, penetration of daylight, macro- and micro-fauna of the intertidal zone, the sessile flora and fauna of the buoys, the fishes and their food, and the birds which frequent the flats and channels. Other studies are contemplated. In the work on light penetration and on quantitative estimates of the fauna of the mud-flats, no comparable data have hitherto been procured in this country.

The Tamar is the largest of the rivers which flow into the west end of Plymouth Sound. It is tidal for nearly 19 miles $(30 \mathrm{~km}$.) of its course. Rather over 3 miles $(5.5 \mathrm{~km}$.) from the sea it is joined by the River Lynher to form the Hamoaze, an estuary common to the two rivers. About 6 miles $(9.5 \mathrm{~km}$.) from the sea it is joined by its main tributary, the River Tavy. The Tamar flows over geological formations of Devonian and Carboniferous slates, shales, and grits. The Tavy flows over the same formations but rises among the peat bogs overlying the Dartmoor granite. The Lynher and its tributary, the St Germans River, also rise on granite, but they run for most of their length over Carboniferous rocks.

\section{EstuARINe Deposits}

Among the more conspicuous features of the whole estuarine area are the mud-flats, often of considerable extent, which border the river channel. Mud has been so extensively deposited as to constitute the predominating element of the bottom in the intertidal zone. Even in the lower reaches of the estuary 
the deposits extend well up into the high-water zone, impregnating the "shillet" or stony ground which is characteristic of long stretches of shoreline. There is a marked contrast with the conditions in the Kingsbridge Estuary, where a zone of clean stones and gravel, bearing rich growths of algae, extends down to below high-water neaps. In the Tamar and its branches rocky outcrops clear of silt at the higher levels are relatively infrequent, but occur as far up the river as Neal Point. As the river mouth is approached the mud deposits do not give place to sand, as in neighbouring estuaries such as the Erme and Avon.

As may be seen on the accompanying plan (Plate XVIII), the intertidal areas occupy a large fraction of the estuary bed, and by far the greater part of these consist of the deposits referred to. They fill all the inlets and irregularities in the contours of the shore-line, tending to confine the main flow of the river and tidal streams to a central channel. Owing to their large area and to the abundance of the fauna for which they provide a habitat, these mud-banks acquire considerable importance in the ecology of the estuary; and while it would be out of place here to enter into details of their physiography, certain general features may be pointed out.

It may be noticed that the contours of the mud-banks are rarely such that a cross-section of the estuary bed shows an even decrease of level from the shore towards mid-channel; the banks tend to flatten out and acquire a steeper slope on their outer face. The levelling process has often gone so far that in any place a large proportion of the surface of the mud-bank will lie between certain narrow limits of vertical height. Since change in vertical height implies change in the amount of exposure to the air on the ebb tide, or of exposure to varying salinities on the flood, this factor is important in faunistic studies. For brevity we may refer to those regions of the mud-banks where the gradient is at a minimum as "flats". As a general rule not only do the flats include a considerable fraction of the total area of a bank, but also, as they are apparently usually subjected to least disturbance from currents, they provide the most favourable habitat for the mud fauna. Consequently it is important to note, in any area, the levels at which the flats occur.

In the first place it emerges that though, where the estuary is broad, the flats may extend well below the permanent water channel (as off West Muds, and at the junction of the Tavy), they are more usually mainly or entirely intertidal. Secondly, as the estuary is ascended, and as the rock bed of the estuary rises, so rises the average level of the mud-flats. One effect of this is that an increasing proportion of the intertidal zone is uncovered at half-tide. In many places the approximate level of the half-tide line has been ascertained and is shown on the plan (Plate XVIII). Both the estuaries of the Tamar and Tavy above their junction show this phenomenon fairly diagrammatically, while smaller branches such as St John's Lake and Millbrook Lake provide excellent examples in miniature. Above a certain point the area between halftide and the channel comprises a nearly uniform narrow zone with a relatively 
steep gradient; while the greater part of the mud-bank lies above, with a lesser gradient which varies with the breadth of the tidal zone. A great proportion of the fauna of these mud-banks is thus saved from the low salinities which prevail on the ebb tide. Also, as the river is ascended, birds have increasing opportunities over fish as predators of the mud fauna.

Another aspect of the up-river rise of the level of the mud-banks is that, unless currents interfere, mud is more freely deposited near high-water springs. As a result the substratum in the zone between high-water springs and neaps becomes increasingly favourable, where the gradient permits, for the development of saltings. The salting flora, of which Salicornia is the pioneer, is able to establish itself on flat stretches below the level of ordinary tides, where it is uncovered for no more than two or three consecutive days. $\mathrm{Up}$ river all the flatter (and so broader) ground between ordinary high water and springs is occupied by saltings. It is common knowledge that once saltings have become established they accelerate the deposition of silt, and so rise more rapidly than the adjoining areas of clear mud. At the same time erosion of the edges produces an increasingly abrupt transition line between the clear mud and the salting, the boundary of which comes to be marked by a "salting cliff". Various stages in this process may be seen passing from Salt Mill to Egypt Salt Marsh to Clifton. In the latter vicinity the salting cliff attains the height of $\mathrm{I} \mathrm{m}$. In the upper reaches of the estuary the top of the salting cliff approximately coincides with the level of ordinary tides ( $+\mathrm{I} \cdot 7 \mathrm{~m}$. O.D.). The greater part of the saltings on the Tamar above Cargreen, and on the Lynher above Sheviock Wood, are uncovered for the whole week of neap tides.

Saltings tend to fill up all the irregularities in the contours of the spring-tide shore-line. This natural, but slow, process of land reclamation has in some places been completed artificially by the construction of embankments and drainage ditches (at Landulph, on the north side of Kingsmill Lake; and opposite Pentillie). A large inlet cut off by Ernesettle railway embankment has also been reclaimed during the past century.

In the upper reaches the river is in many places bounded by steep slopes. The mud-banks here are narrower, but still show an increasing gradient on their outer face. For considerable stretches steep hanging woods extend to the river's edge. In winter great quantities of sodden leaves accumulate in the river, and are deposited in the mud on the inner sides of curves near low-water mark, as well as along the channel in deeper water.

When a winter flood is beginning to decrease a layer of fine, sticky, grey mud, locally called "slurry", is deposited on the flats, and lies there until scoured away by the next spring tides. This may be responsible for temporary fluctuations in the level of certain flats.

In general the mud-banks appear to have considerable stability, and their growth, below the level of saltings at least, appears to be extremely slow. It is difficult to detect any appreciable changes during recent years. Signs of growth might be expected in a situation such as the east shore above Saltash, 
where a railway embankment raised from a level lying below half-tide has provided a new shore-line. The survey of a traverse in 1937 can be compared with the Admiralty Chart surveyed in I894. Though a significant difference is found, it cannot be considered great. The bank appears to have risen nearly a metre in the centre, but scarcely at all on the face of the embankment. The result is that the bank rises somewhat more steeply from the river, is more level on its main expanse, but still remains well below the half-tide level.

The consistency of the mud deposits may be described as "soft", as contrasted with that of stiffer muds which contain a large admixture of fine sand. Progress over the banks is often difficult, a man usually sinking above the ankles at each step, and often to the knees. Surface samples from different situations vary most in the materials which are mixed with the silt. Valves of mollusc shells are almost always present, sometimes comprising the main bulk of the deposit. Vegetable residues ranging from very finely divided shreds to whole leaves and pieces of twig are always present, though in extremely variable quantities. But there is a marked absence of admixture of sand particles, and gravel is only obtained from sievings of samples taken near high water in the lower reaches. Thus the more solid components of the mud deposits consist almost entirely of valves of mollusc shells and their fragments. Cardium edule, Scrobicularia plana, Peringia ulvae, and Littorina littorea are the main species concerned. Their abundance is sometimes such that they form a conspicuous feature of the landscape, as they lie thickly strewn on the surface of the flats, or accumulated in a mass along the course of drainage channels.

\section{Depth of the Channel and Tidal Range}

In the harbour area (Hamoaze) the river channel attains a considerable depth, attaining $37.8 \mathrm{~m}$. (I24 ft.) near Devil's Point. The depth steadily decreases northward. Beyond $5 \mathrm{~km}$. from the mouth only two small depressions exceed $15 \mathrm{~m}$. ( $49 \mathrm{ft}$.). The Lynher shallows to a maximum of $5 \mathrm{~m}$. at the point where it widens, and to the order of $\mathrm{I} \mathrm{m}$. at Sheviock Wood. The main river shallows rapidly above Saltash Bridge, and above the junction of the Tavy only just exceeds $5 \mathrm{~m}$. in two places. At Cargreen there is a slight indication of a decrease in average tidal fall (see Table II), but this does not become pronounced until the bend in the river above Clifton. However, at Pentillie Quay, $16.5 \mathrm{~km}$. from the mouth, it is only $0.62 \mathrm{~m}$. less than at Devonport. The subsequent rise of the river bed relative to sea-level is very gradual in the winding Tamar, and the influence of the tide does not die out until $30 \mathrm{~km}$. from the mouth. The bed of the Tavy, however, rises much more quickly. Even at Bere Ferrers it has apparently risen above Chart datum. Tidal influence soon disappears after the narrowing of the river at Lopwell, at some $17 \mathrm{~km}$. from the mouth.

The depth of the channel in the harbour area ensures a strong tidal scour of the lower reaches of the estuary, and checks the encroachments of the mud- 
banks. Dredging operations help in the same direction, and there has apparently been little change in the bed of the Hamoaze in recent years. However, from the junction of the Lynher to Saltash an appreciable shallowing has taken place. In the upper reaches, too, the local watermen say the channel is becoming shallower. They attribute this to the fact that small paddle steamers no longer run between the villages along the shores. The churning of the paddle wheels may well have artificially affected the depth of the channel at some points, but noticeable changes subsequent to the removal of this influence are more likely to involve a return to a normal equilibrium than a renewal of a progressive silting.

The data relating to the tide levels are given in Table I. It will be observed that the mean range of tide is $4.73 \mathrm{~m}$. (I5.52 ft.) for spring tides, and $2.34 \mathrm{~m}$. ( $7.65 \mathrm{ft}$.) for neaps, extremes in 1937 being 5.55 and $\mathrm{I} \cdot 44 \mathrm{~m}$. respectively. Table II gives the relative tidal range at seven positions in the tidal area, following the Channel Pilot.

Table I. Tidal levels at Devonport in Relation to

ORdnance SuRvey Datum

Highest predicted tide 1937

Mean high-water springs

Mean high-water ordinary tides*

Mean high-water neaps

Lowest predicted high tide 1937

Mean sea-level

Land Survey (Ordnance) Datum

Mean tide, Devonport

Highest predicted low tide 1937

Mean low-water neaps

Mean low-water ordinary tides*

Mean low-water springs

Admiralty Datum

Lowest predicted tide 1937

$\begin{array}{cc}\text { Metres } & \text { Feet } \\ +2.53 & +8.3 \\ 2.22 & 7.28 \\ 1.70 & 5.58 \\ 1.17 & 3.83 \\ 0.70 & 2.3 \\ 0.22 & 0.73 \\ 0.0 & 0.0 \\ -0.08 & -0.27 \\ -0.77 & -2.52 \\ -1.165 & -3.82 \\ -1.82 & -6.00 \\ -2.51 & -8.24 \\ -2.566 & -8.42 \\ -3.02 & -9.9\end{array}$

* The high- and low-water contours are inserted on the plan (Plate XVIII), following the practice of Ordnance maps.

\section{Table II. Relative Tidal Ranges at Springs}

\begin{tabular}{l}
\multicolumn{1}{c}{ Position } \\
Devonport Dockyard \\
Saltash, River Tamar \\
Cargreen, River Tamar \\
Pentillie, River Tamar \\
Calstock, River Tamar \\
Warleigh Quay, River Tavy \\
Maristow, River Tavy
\end{tabular}

Distance from
mouth in
$\mathrm{km}$.
3
6.8
II
I6.5
22
I0.5
14

\begin{tabular}{|c|c|}
\hline \multicolumn{2}{|c|}{ Tidal range } \\
\hline Metres & Feet \\
\hline $\begin{array}{l}4.7 \\
4 \cdot 6\end{array}$ & $\begin{array}{l}15.5 \\
15.0\end{array}$ \\
\hline $\begin{array}{l}4.0 \\
4.5\end{array}$ & I4.75 \\
\hline $4 \cdot \mathrm{I}$ & 13.5 \\
\hline $3 \cdot 8$ & I $2 \cdot 5$ \\
\hline $\begin{array}{l}4.4 \\
2.6\end{array}$ & $\begin{array}{r}14.5 \\
8.5\end{array}$ \\
\hline
\end{tabular}

There is considerable eddying of the tidal stream within the river. Close inshore there is a current running in the opposite direction to the set of the tide-the so-called "eddy tide". When much fresh water is coming down, the 
flood tide will move up on one side of the river before its influence reverses the direction of the surface flow upon the other. The two bodies of water may be distinguished by the line of floating leaves and debris where they meet and by the muddiness of the fresh water. The upward flow of the rising tide is first felt along the bottom of the river.

A southerly gale will choke back the tide in the estuary so that the water level at the slack of the ebb may be several feet above that predicted. When the next rising tide drives in before the storm, considerable flooding may take place. A northerly gale will cause a stronger ebb than usual and a depression of high-tide level.

The greatest speed of the tidal stream within the harbour is $2 \frac{3}{4}$ knots (Channel Pilot).

\section{RAINFALL}

Along the valleys of the Tamar and its tributaries the mean annual rainfall is from 950 to II $50 \mathrm{~mm}$. per annum: but the drainage area lies between two of the wettest places in the west of England-Dartmoor and the Cornish moors. At Princetown, on Dartmoor, the normal rainfall is $2079 \mathrm{~mm}$. per annum, and at Altarnun on the Cornish side, $1503 \mathrm{~mm}$. In Table III is shown the rainfall at Plymouth near the mouth of the river (normal annual rainfall: $933 \mathrm{~mm}$.) and at Princetown.

\section{TABLE III}

\begin{tabular}{|c|c|c|c|c|c|c|}
\hline \multirow[b]{2}{*}{ Months } & \multicolumn{3}{|c|}{ Plymouth } & \multicolumn{3}{|c|}{ Princetown } \\
\hline & Normal & r936 & I937 & Normal & 1936 & I937 \\
\hline Jan.-Mar. & 233 & 388 & $43 I$ & 568 & 612 & $94 \mathrm{I}$ \\
\hline Apr.-June & 166 & 87 & 189 & 339 & 218 & 332 \\
\hline July-Sept. & 213 & 254 & 126 & 439 & 622 & 324 \\
\hline Oct.-Dec. & $32 \mathrm{I}$ & I99 & 304 & 733 & 604 & $4 \mathrm{II}$ \\
\hline
\end{tabular}

During the first three months of both years the rainfall was greatly in excess of the normal. In July 1936, the rainfall was greater than normal and floods of thick, brown water came down from the moors. The rest of the summer of 1936 and the summer of 1937 were drier than usual.

\section{Human Activities}

A small and diminishing population of fishermen work in the estuaries of the Tamar and Lynher. Large seines for salmon and sprats are used, and a modified shore-seine, the "Saltash Tuck Seine", is used for the capture of flatfishes. In the autumn, herrings are caught in drift-nets. Motor boats from Plymouth trawl for prawns in the harbour area, and some shrimps and prawns are taken in hand-nets during the summer. On the flats of West Muds winkles and cockles are gathered; cockle beds outside Skinham Creek are also picked over occasionally. Mussels from the river are not saleable, and the oyster beds (near Saltash) are worked out. After December 1937, the sale of all shellfish from the estuaries was prohibited by the local 
medical authorities. Only one professional punt-gunner now works in these waters, and there is very little shore-shooting. Above Hole's Hole rotten leaves are collected from the flats for use as manure.

The eastern side of the Hamoaze from Devil's Point to Bull Point is covered by the quays and buildings of Devonport Dockyard. There is no pollution of the rivers by commercial effluents. A number of sewers release crude sewage into the channels: much of this matter is at once eaten by the mobs of gulls which haunt the outfalls. Unlike certain other rivers which flow off Dartmoor and the Cornish moors, those in this watershed never carry the milky white suspension derived from China-clay washings. Pollution by crude oil residues, as far as it can be determined by the presence of oiled sea-birds or stranded clots, is not found in the estuary. Small quantities of lighter oils are constantly being discharged in the harbour area from motor-driven vessels, but it is extremely questionable whether these have any harmful effects, and even if proof of such is ever obtained, the extent to which it occurs is very probably negligible.

\section{Previous BIOLOGICAL WORK}

Duncker (1899) made a statistical examination of flounders caught in the Tamar. Ford (I928) fished for young herring with a small-meshed seine-net in the Tamar, Tavy, and Lynher, and published his results in the fourth paper of "Herring investigations at Plymouth". In I929 Percival published the results of an investigation of the fauna of the Tamar and Lynher, carried out between June and November, I928. The paper contains a description of the area, an annotated faunistic list, and some observations on salinity variations. Percival points out that 1928 was an unusually dry summer. Certain analyses of his data are made in the Survey of the River Tees, Part II (pp. 79-8I). After Serventy (1935) had recorded the occurrence of Gammarus zaddachi in the Tamar, Crawford (1937) made a more detailed study of the distribution of certain Crustacea (Tanaidacea, Isopoda, and Amphipoda) in the estuarine zone of the three main rivers. Moore's studies on the biology of Balanus (1936) and Littorina littorea (1937) deal with populations of these animals from Henn Point and Treval respectively.

\section{Note}

In the spelling of place-names we follow the Ordnance Survey, but it should be pointed out that for some names alternative spellings are still in use. Thus Neal Point is variously "Neil" (Admiralty Chart) or "Neille" (Percival, 1929; Crawford, I937). Another locality appears to be "Treval" or "Trevol", according as it is approached from the land or the water! There are names such as Warren Point which recur in this and other estuaries with inconvenient frequency, and care should be employed in their use. In Crawford's map (1937, p. 649) the names Bull Point and Weston Mill Lake are misplaced.

Various information, such as depths, has been derived from the following 
Admiralty Charts: Plymouth Sound and Hamoaze, surveyed I898-9, with large corrections to I93I, and small corrections to I937; Tamar River (Saltash to Cargreen), surveyed I894, with additions to 1905; entrance to St Germans or Lynher River, surveyed 1923, with small corrections to 1937.

The information given here on intertidal levels, e.g. the half-tide line, is based on the survey of certain traverses made in 1936-7, supplemented by observations on the state of the tide in a general view of stretches of estuary, at the appropriate time and in suitable weather conditions. No great exactness is claimed.

\section{REFERENCES}

Admiralty Tide Tables, for 1937 and 1938. H.M. Stationery Office, London. 1936 and I937.

AlexandER, W. B., Southgate, B. A., and Bassindale, R., 1935. Survey of the River Tees. Part II. The Estuary-chemical and biological. D.S.I.R. Water Pollution Research, Tech. Paper No. 5, H.M. Stationery Office.

Channel Pilot, Part I. Ninth edition. Admiralty. I900.

Twelfth edition. Admiralty, 193I. With Supplement No. 5, including corrections to November I0 1937.

CRAWFORD, G. I., I937. The fauna of certain estuaries in west England and South Wales, with special reference to the Tanaidacea, Isopoda, and Amphipoda. fourn. Mar. Biol. Assoc., Vol. xxI, pp. 647-62.

Duncker, G., I899. Variation und Asymmetrie bei Pleuronectes flesus L. Wiss. Meeresuntersuch. Abt. Helgoland, Bd. III, pp. 333-406.

ForD, E., 1928. Herring investigations at Plymouth. IV. The growth of young herrings in the neighbourhood of Plymouth. Fourn. Mar. Biol. Assoc., Vol. xv, pp. 305-I9.

Meteorological Office. 1924. The Book of Normals of Meteorological Elements for the British Isles for Periods ending I915. Section V.

Moore, H. B., I936. The biology of Balanus balanoides. V. The distribution in the Plymouth area. Fourn. Mar. Biol. Assoc., Vol. xx, pp. 70I-I6.

- 1937. The biology of Littorina littorea. Part I. Growth of the shell and tissues, spawning, length of life and mortality. Fourn. Mar. Biol. Assoc., Vol. XxI, pp. $72 \mathrm{I}-42$.

Percival, E., I929. A report on the fauna of the estuaries of the River Tamar and the River Lynher. Fourn. Mar. Biol. Assoc., Vol. xvi, pp. 81-108.

SERVENTY, D. L., I935. Observations on Gammarus zaddachi Sexton, an estuarine amphipod, and associated forms. Int. Rev. Hydrob. Hydrogr., Vol. xxxiI, pp. 285-94. 


\section{PLAN OF THE \\ TAMAR ESTUARY BASIN}

The Intertidal zone between Ordinary High and Low Water marked in fine stipple.

Saltings indicated by coarse irregular stippling.

Only the main streams through the intertidal zone are inserted. Ramifying channels through saltings are omitted. Fresh-water streams flowing into the estuary are not traced to their source.

The dotted line dividing the intertidal zone represents the approximate position of half-tide where this has been ascertained.

Contours in the permanent channel are given at intervals of $5 \mathrm{~m}$. depth below Admiralty datum. The deeper part of the channel exceeding $15 \mathrm{~m}$. (approximately 8 fathoms or $50 \mathrm{ft}$.) is blackened.

The course of the main river, the Tamar, is marked in kilometre intervals from the mouth (zero position at the level of Devil's Point).

Certain mooring buoys from Plymouth Sound to Saltash are marked as follows. D I to 4: Drake's Island Buoys. Cr. By.: Cremyll Buoy. $H$ I to I5: Hamoaze Buoys, Nos. I to 15 .

The plan is orientated $\left(2^{\circ} \mathrm{W}\right.$. of N.) with respect to the Ordnance Survey National Grid, of which rooo yard intervals are marked along the border. The lower section covers $820 \cdot 5-833.66$ (thousand yards) E. and I66.86I $74.06 \mathrm{~N}$. The upper section covers $825 \cdot \mathrm{I}-833.66 \mathrm{E}$. and $173.57-181.5 \mathrm{~N}$.

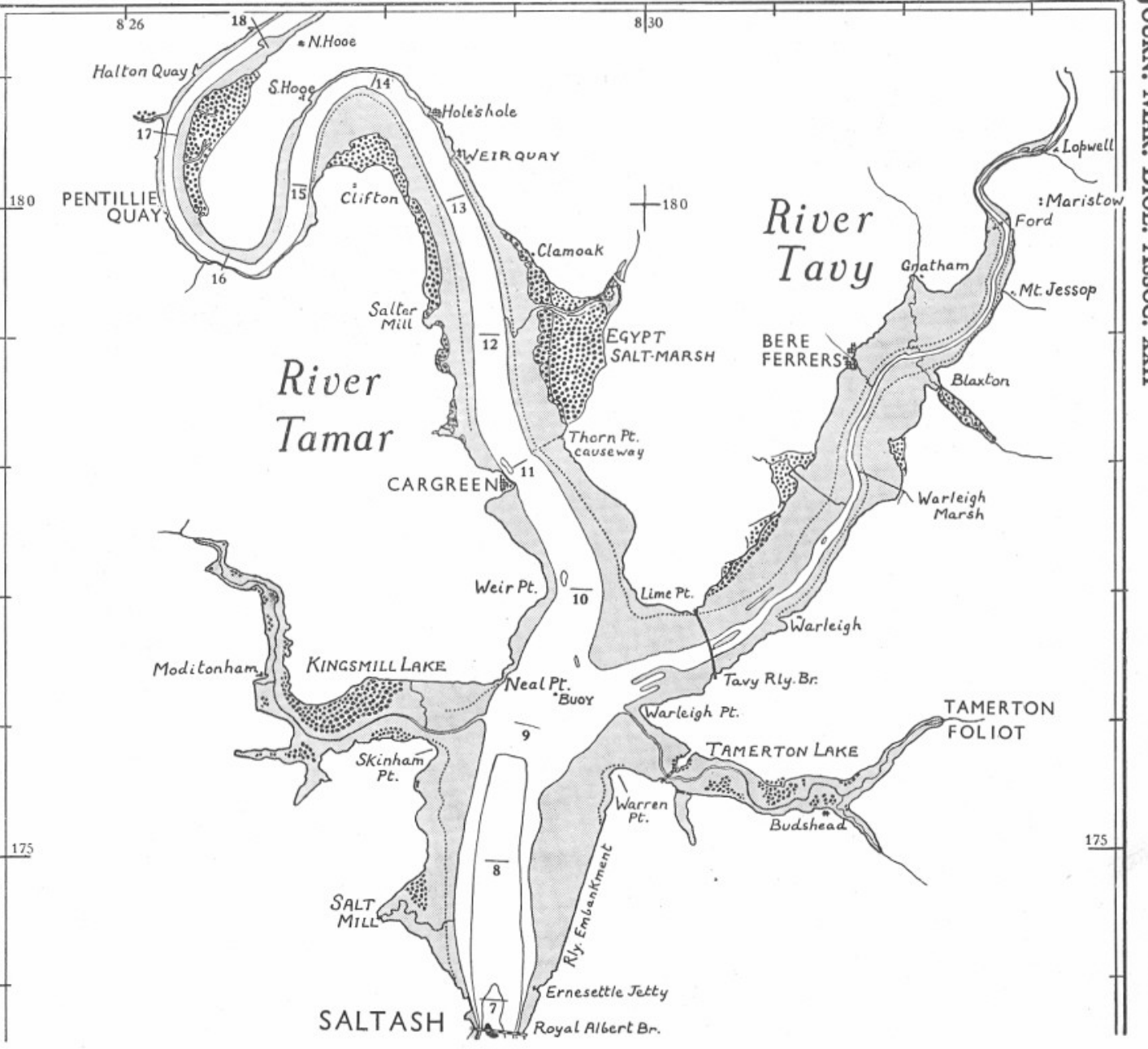




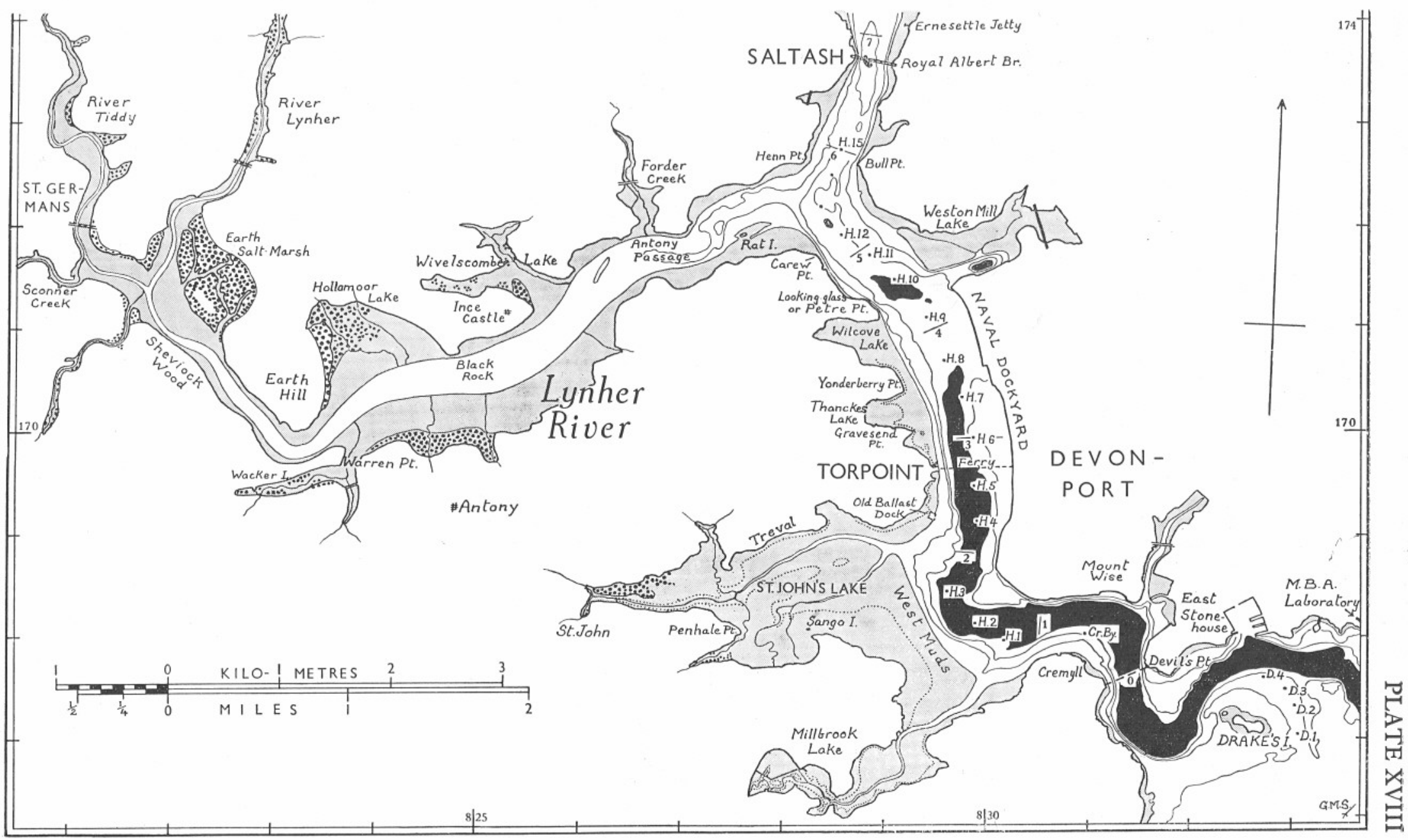

